\title{
Study on Leaching Characteristics and Bio-availability of Heavy Metals in Soil of the Lead and Zinc Mine
}

\author{
He Xuwen1*, Fang Zengqiang, Wang Yuxiang, Jia Mengyao, Song Junying, Wang Qifan, Hu Maoguan \\ School of Chemical \& Environmental Engineering, China University of Mining \& Technology（Beijing），Beijing \\ 100083, China; \\ hexuwen@sina.com.cn; 891698088@qq.com; 531523128@qq.com; 495790169@qq.com; 1530417907@qq.com; \\ 284268058@qq.com; 897805686@qq.com
}

\begin{abstract}
Abstact--In order to study the pollution level and leaching characters of the heavy metals in the soil of lead-zinc mining area, soil sample in a lead and zinc mine of Hunan is taken as study object. The concentration of heavy metals was analyzed byinductively coupled plasma massspectrometry after microwave digestion of soil. TCLP (toxicity characteristic leaching procedure), PBET (physiologically based extraction test) and DTPA (diethylene triamine pentacetic acid) extraction experiments of soil was conducted. Results show that concentrations of heavy metals from high to low is $\mathrm{Zn}>\mathrm{Pb}>\mathrm{Cd}>\mathrm{Cr}>\mathrm{Cu}>\mathrm{Ni}>\mathrm{As}$. The highest leaching ratio of TCLP and DTPA is Cd (6.83 E-04) and $\mathrm{Zn}(1.14 \mathrm{E}-0)$ respectively. The highest biological effectiveness of heavy metal in soil is $\mathrm{Zn}\left(0.82 \mathrm{mg} \cdot \mathrm{L}^{-1}\right)$. Keywords-Hunan; Soil; Heavy metal; leaching characteristics; bio-availability;

\section{INTRODUCTION}

Heavy metal, as a kind of persistent potentially toxic pollutants ,once be released into the environment, can endanger the human body and ecological security, because it can not be biodegradable and exist in environment for a long time[1].By studying the content [2.3] and speciation[4] of heavy metal around the mining area environment, some scholars discovered that long-term exploitation of mines and arbitrary disposition of mineral waste residue can cause the local environment serious heavy metal pollution and lead to become one of the common problems existing
\end{abstract}

in the mining area, which not only affect the mine self-development but also the people life and agricultural production around mining area. Heavy metals in the soil can not only affect plant growth, but also influence and change the ecological function of the soil [5-7]. The migration, transformation and the harm to environment of heavy metal have a lot to do with its existence form in the soil beside the content of heavy metals [8-10]. Therefore, study on the pollution level, leaching characteristics and bio-availability of heavy metals in soil is of great significance.

II. MATERIALS AND METHODS

\section{A. Research Materials}

The study was conducted in Maxipu in Yuanling County, Huaihua City in Hunan province (Fig .1). Sampling was conducted randomly in an area around the mine, with 8 composite soil samples marked as S1-S8. Four sub-samples were collected in each sample site.and the sampling depth was between 0-20 $\mathrm{cm}$. Soil samples collected were stored in polyethylene bags for transport and storage, and were air-dried, then sieved through a $2.0-\mathrm{mm}$ mesh sieve to remove stones, coarse materials and other debris. After that, the samples were placed in sealed polyethylene container, labeled and wait to use.

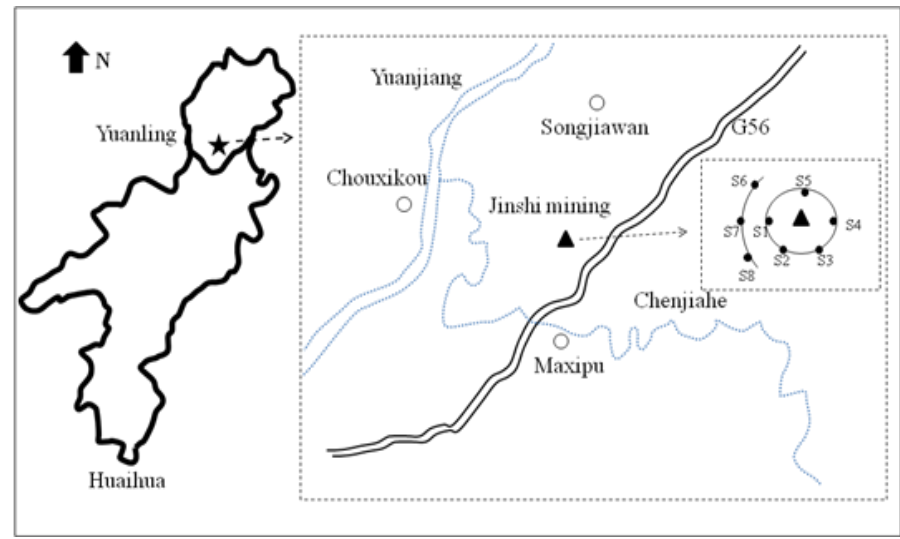

Figure1. Location of investigation area and sampling sites 


\section{B. methods}

Accurately weighed sample powder $0.2 \mathrm{~g}$, take samples and placed in Ptfe digestion pot, add 2-3 drops of deionized water to wetting, add $6 \mathrm{ml}$ nitric acid, 6 $\mathrm{ml}$ hydrofluoric acid and $2 \mathrm{ml}$ hydrochloric acid. After microwave digestion, cooling add to $50 \mathrm{ml}$ with $1 \%$ nitric acid, save at $4{ }^{\circ} \mathrm{C}$. Concentrations of heavy metals were measured by ICP-AES and AFS (atomic fluorescence spectrometry).

(1) TCLP(toxicity characteristic leaching procedure): Add $5.7 \mathrm{ml}$ glacial acetic acid in the volumetric flask, then add deionized water to $1 \mathrm{~L}$ and keep $\mathrm{pH}=2.88 \pm 0.05$. The dosage of the buffer is 20 times of soil. It is oscillated with the speed of $(30 \pm 2) \mathrm{r} \cdot \mathrm{min}^{-1}$ at room temperature for $18 \pm 2$ $\mathrm{h}$. After centrifugal filtration, the $\mathrm{pH}$ of leaching agent was adjust to 2 with $1 \mathrm{~mol} \cdot \mathrm{L}^{-1} \mathrm{HNO}_{3}$.

(2) PBET (physiologically based extraction test): PBET extracting solution: $0.4 \mathrm{~mol} \cdot \mathrm{L}^{-1}$ glycine buffer solution ( $\mathrm{pH}=1.5 \pm 0.05$ ). $2.5 \mathrm{~g}$ sample powder was mixed with $250 \mathrm{~mL}$ extracting solution $\left(37^{\circ} \mathrm{C}\right)$, then was put into an polyethylene bottle. The mixed liquor was rotated up and down at the speed of $30 \pm 2 \mathrm{rpm}$ for $1 \mathrm{~h}$ at $37{ }^{\circ} \mathrm{C}$ to simulate the condition and residence time of the sludge in mammals intestines and stomach $(\mathrm{pH}=1.5 \pm 0.05)$. After centrifugal filtration, the $\mathrm{pH}$ of leaching agent was adjust to 2 with $1 \mathrm{~mol} \cdot \mathrm{L}^{-1} \mathrm{HNO}_{3}$.

(3) DTPA- extraction: DTPA extracting solution: $0.005 \mathrm{~mol} \cdot \mathrm{L}^{-1} \mathrm{DTPA}+0.01 \mathrm{~mol} \cdot \mathrm{L}^{-1} \mathrm{Cacl}+0.1 \mathrm{~mol} \cdot \mathrm{L}^{-1} \mathrm{TEA}$. $5 \mathrm{~g}$ sample powder was put into $25 \mathrm{ml}$ DTPA extracting solution $(\mathrm{pH}=4.1)$. The mixed liquor was vibrated for $1 \mathrm{~h}$ at room temperature. After centrifugal filtration, the $\mathrm{pH}$ of leaching agent was adjust to 2 with $1 \mathrm{~mol} \cdot \mathrm{L}^{-1} \mathrm{HNO}_{3}$.

\section{RESULTS AND ANALYSIS}

The soil sample collected in the area is alkaline, the $\mathrm{pH}$ of which around 7.8 (Table 1). The organic matter content in the soil is around $10.3 \mathrm{~g} \cdot \mathrm{kg}^{-1}$. There are also some nitrogen, phosphorus and potassium elements in the soil. The content of total nitrogen in soil samples is around 0.21 $\mathrm{g} \cdot \mathrm{kg}^{-1}$; the content of total phosphorus in soil samples is around $1.32 \mathrm{~g} \cdot \mathrm{kg}^{-1}$; the content of total potassium in soil samples is around $2.81 \mathrm{~g} \cdot \mathrm{kg}^{-1}$. From the results, we can see the main physical and chemical properties of the selected soil are closing to the main physical and chemical properties of normal soil.

TABLE1. Physical and chemical indicators of soil $\left(\mathrm{g} \cdot \mathrm{kg}^{-1}\right)$

\begin{tabular}{llllll}
\hline Items & $\mathrm{pH}$ & Organic matter & Total N & Total P & Total K \\
\hline Soil & $7.8 \pm 0.1$ & $10.3 \pm 0.1$ & $0.21 \pm 0.02$ & $1.32 \pm 0.01$ & $2.81 \pm 0.12$ \\
\hline
\end{tabular}

\section{A. Pollution level}

The content of $\mathrm{Zn}, \mathrm{Pb}, \mathrm{Cd}, \mathrm{Cr}, \mathrm{Cu}, \mathrm{Ni}$, As in the soil was tested after the microwave digestion of the soil, and the results showed that the heavy metal content of the soil in the area is high on the whole(Fig .2). The highest level of heavy metals in the soil is $\mathrm{Zn}(2333.7 \mathrm{mg} \cdot \mathrm{kg}-1)$, while the lowest is As (78.1 $\mathrm{mg} \cdot \mathrm{kg}-1)$. Heavy metal concentration in soil is from high to low in turn is $\mathrm{Zn}>\mathrm{Pb}$ $>\mathrm{Cd}>\mathrm{Cr}>\mathrm{Cu}>\mathrm{Ni}>\mathrm{As}$. As we can see the concentrations of $\mathrm{Zn}$ and $\mathrm{Pb}$ are higher than the concentration of other heavy metals, because the soil sample taken from lead-zinc mining area.

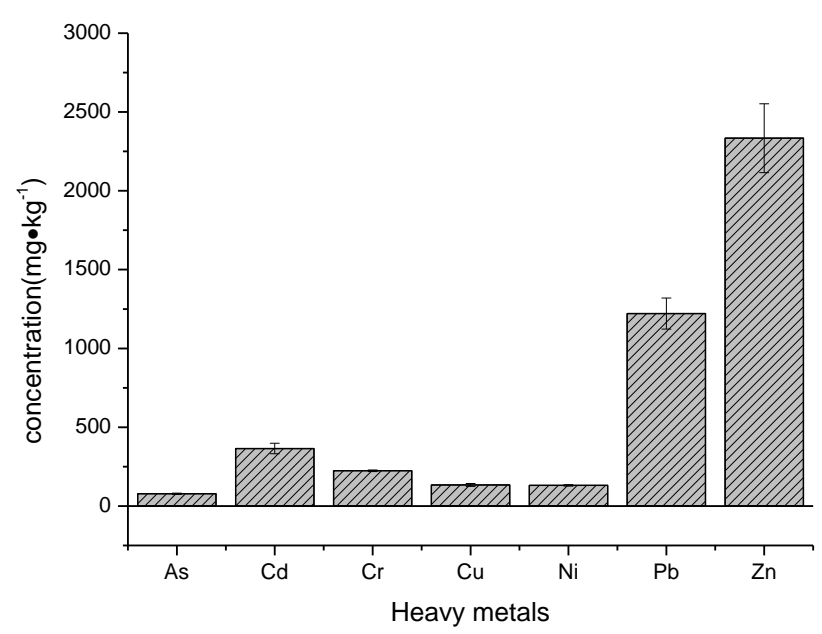

Figure2. Concentration of heavy metals in the soil

\section{B. Leaching characteristics}

The leaching experiment of soil sample was conducted by three kinds of extract liquid, and results show that heavy metal concentration in leachate is different even though heavy metal concentration in soil is the same. In
TCLP leaching experiment, the highest concentration of heavy metal in leachate is $\mathrm{Zn}(1.0 \mathrm{mg} \cdot \mathrm{L}-1)$, while the highest leaching ratio is Cd; In DTPA leaching experiment, the highest concentration of heavy metal in leachate is $\mathrm{Pb}$ (1.2 $\mathrm{mg} \cdot \mathrm{L}-1)$, and the highest leaching ratio is $\mathrm{Cd}$; The 
highest biological effective state content in soil is zinc, and effective state concentration is $0.8 \mathrm{mg} \cdot \mathrm{L}-1$ (Fig .3). The leaching concentration of heavy metal is different because different extract liquid has different property and heavy metals in soil have different forms.
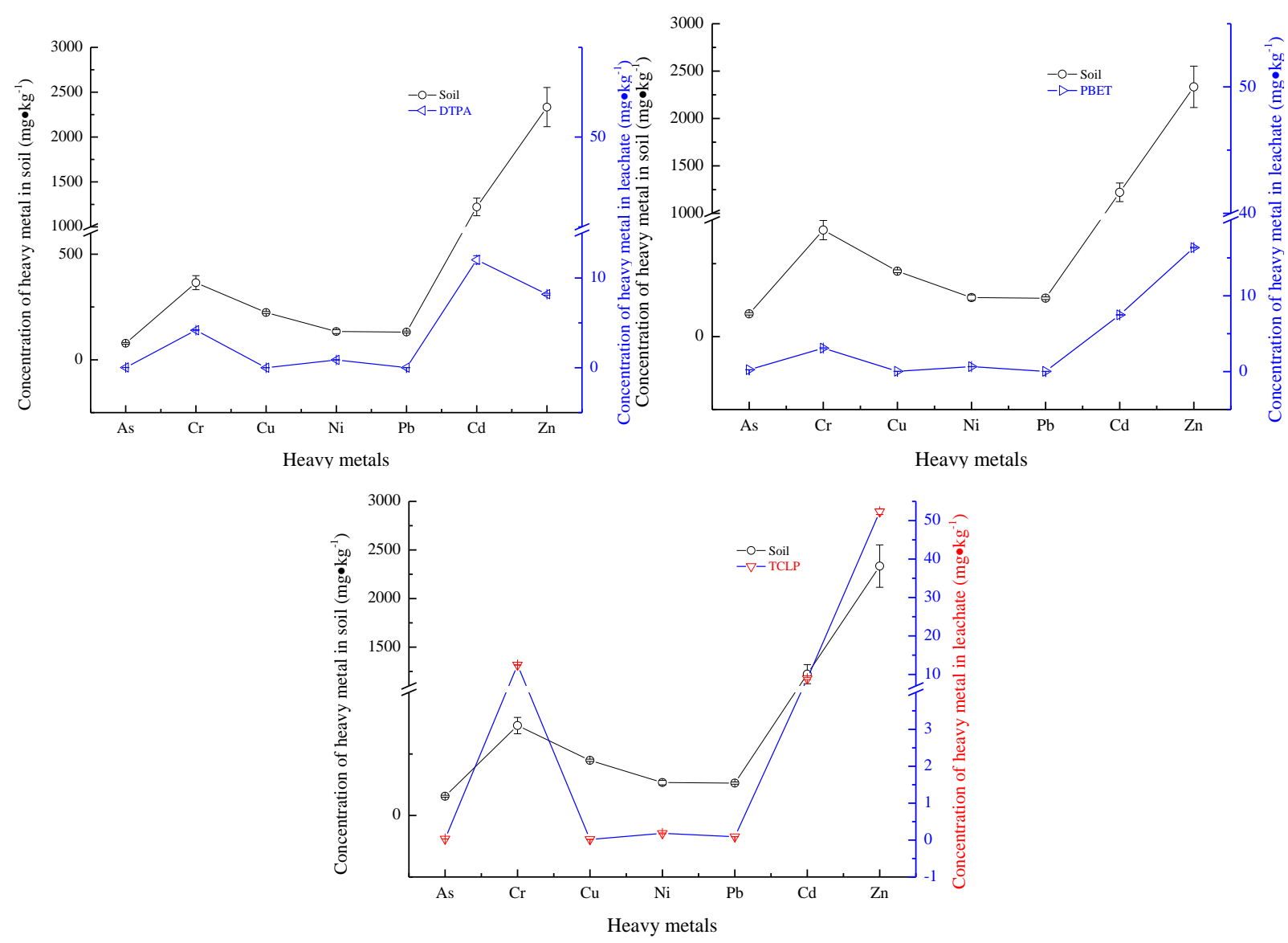

Figure3. Comparison of heavy metal concentration in the soil and leachate

As Fig .4 shows that different extract liquid has different extract ability for the same heavy metal in the soil. As is more likely extracted by PBET extract liquid, followed by TCLP and DTPA; Cr is more likely extracted by PBET extract liquid, followed by TCLP and DTPA; $\mathrm{Cu}$ is more likely extracted by DTPA extract liquid, followed by PBET and TCLP; Ni is more likely extracted by TCLP extract liquid, followed by PBET and DTPA; $\mathrm{Pb}$ is more likely extracted by DTPA extract liquid, followed by TCLP and PBET; Cd is more likely extracted by TCLP extract liquid, followed by DTPA and PBET; $\mathrm{Zn}$ is more likely extracted by TCLP extract liquid, followed by PBET and DTPA.

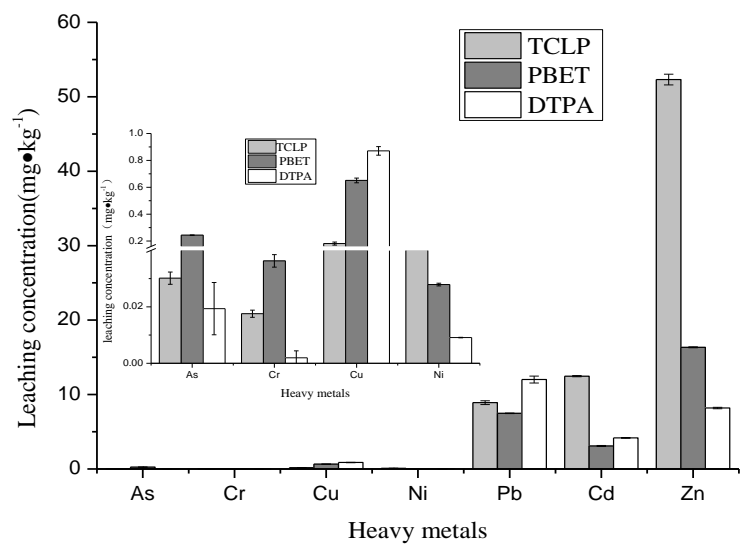

Figure4. Comparison of different leaching experiment 


\section{CONCLUSIONS}

The mineral composition of the soil sample taken from the lead-zinc mining area is complex, and the heavy metal content of the soil in the area is high on the whole and the concentrations of heavy metals from high to low is $\mathrm{Zn}>$ $\mathrm{Pb}>\mathrm{Cd}>\mathrm{Cr}>\mathrm{Cu}>\mathrm{Ni}>\mathrm{As}$. Heavy metal concentration in leachate is different even though heavy metal concentration in soil is the same. What's more, different extract liquid has different extract ability for the same heavy metal in the soil.

\section{ACKNOWLEDGMENT}

This research was supported by Beijing Natural Science Foundation (8152025).

\section{REFERENCES}

[1] Reynders H, Bervoets L, Gelders M, et al.Accumulation and effects of metals in caged carp and resident roach along a metal pollution gradient $[\mathrm{J}]$. Science of the Total Environment, 2008, 391(1):82-95.

[2] Chopin EI, Alloway BJ. Trace element partitioning and soil particle characterisation around mining and smelting areas at Tharsis, Ríotinto and Huelva, SW Spain[J]. Science of The Total Environment, 2007, 373(3):488-500.
[3] Zheng Na,Liu Jingshuang,Wang Qichao et al. Mercury contamination due to zinc smelting and chlor-alkali production in NE China[J].Applied Geochemistry, 2011, 26(2):188-193.

[4] Sahuquillo A, Rigol A, Rauret G. Overview of the use of leaching/extraction tests for risk assessment of trace metals in contaminated soils and sediments[J].TrAC Trends in Analytical Chemistry, 2003, 22(3):152-159.

[5] Wong C S C, Wu S C, Duzgoren-Aydin N S, et al. Trace metal contamination of sediments in an e-waste processing village in China[J].Environmental Pollution, 2007, 145(2): 434-442.

[6] Nriagu J, Blankson M, Ocran K. Childhood lead poisoning in Africa: a growing public health problem [J]. Sci Total Environ, 1996, 181: 93-100.

[7] Dai J, Becquer T, Rouiller J H, et al. Influence of heavy metals on C and $\mathrm{N}$ mineralization and microbial biomass in $\mathrm{Zn}, \mathrm{Pb}, \mathrm{Cu}$, and $\mathrm{Cd}$ contaminated soils[J]. Appl Soil Ecol, 2004, 25:99-109.

[8] Francesco Nannoni, Giuseppe Protano, Francesco Riccobono. Fractionation and geochemical mobility of heavy elements in soils of a mining area in northern Kosovo[J]. Geoderma, 2011, 161(1-2) : 63-73.

[9] Sastre J, Hernandez E, Rodriguez R, et al. Use of sorption and extraction tests to predict the dynamics of the interaction of trace elements in agricultural soils contaminated by amine tailing accident[J]. Science of the Total Environment, 2004, 3(29): 261-281.

[10] Singh V, Agrawal HM. Qualitative soil mineral analysis by EDXRF, XRD and AAS probes[J]. Radiation Physics and Chemistry, 2012, 81: 1796-1803. 